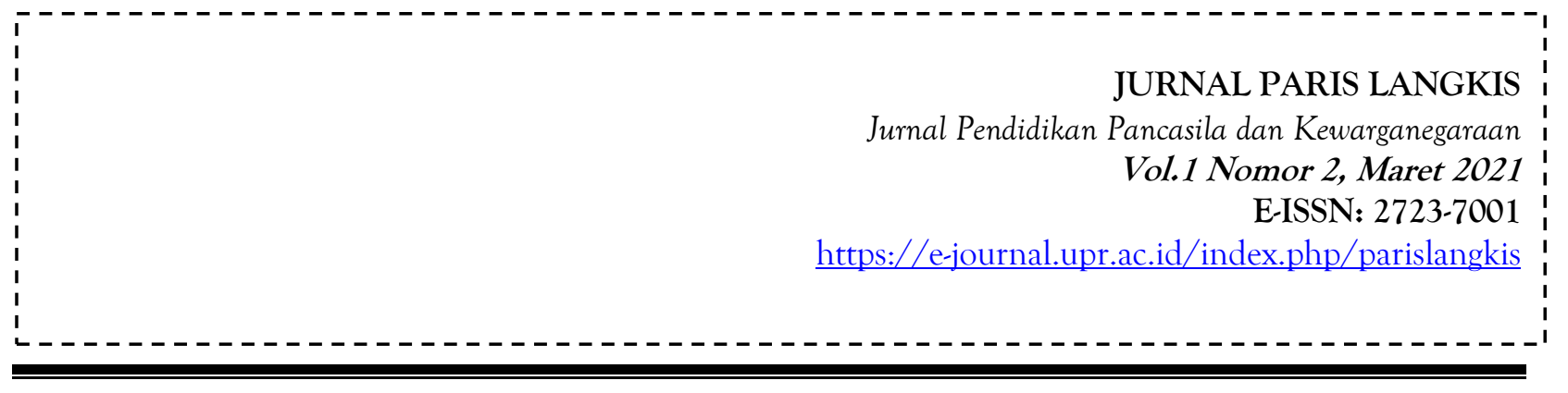

\title{
PENDEKATAN PEMBELAJARAN SOMATIC AUDITORY VISUAL INTELEGENCY (SAVI) DENGAN MENGGUNAKAN MEDIA VIDEO PADA MATERI DINAMIKA PENERAPAN PANCASILA DARI MASA KE MASA DI KELAS IX
}

\author{
Davi Lana ${ }^{1}$, Eli Karliani ${ }^{2}$, Dotrimensi ${ }^{3}$ \\ ${ }^{1,2,3}$ Program Studi PPKn, Universitas Palangka Raya \\ E-mail:davilana170898@gmail.comeli.karliani@fkip.upr.ac.id. ${ }^{2}$,dotrimensi37@gmail.com³
}

\begin{abstract}
Abstrak :
Penelitian ini bertujuan untuk menghasilkan produk media pembelajaran berbentuk video pada mata pelajaran PPkn pada materi dinamika penerapan pancasila dari masa ke masa.Penerapan pembelajaran dengan menggunakan pendekatam SAVI adalah pendekatan ini dapat diterapkan dalam pembelajaran yang ada dikelas dan merupakan suatu alternatif dalam meningkatkan pemahaman dan kreativitas siswa dalam pembelajaran.Selain itu pendekatan SAVI dapat mengarahkan dan membimbing peserta didik untuk belajar secara aktif baik secara fisik maupun intelektual dan mengoptimalkan penggunaan indera yang dimiliki peserta didik.Sehingga mereka lebih mudah menyerap informasi yang disampaikan. Penelitian ini merupakan jenis penelitian dan pengembangan atau Research and Development (R\&D) melalui tahapan : 1) tahap pengumpulan informasi, yakni : Studi literatur, studi pustaka dan kisi-kisi instrument pengumpulan data. 2) tahap perencanaan, yakni : membuat scrip, registrasi powton,editing animasi,voice over, filmora, penggabungan video animasi dan export. 3) tahap pengembangan, yakni : story board dan layout. 4) tahap validasi. Yakni : Ahli materi dan Ahli media. Uji kelayakan pada ahli PPKn dan ahli media dengan subjek uji kelayakan (guru).Uji kelayakan dilakukan dengan lembar validasi.Instrumen penelitian tersebut berupa lembar Validasi, saran dan komentar serta Kuesioner. Hasil dari penelitian ini adalah. 1) Langkah - langkah pengembangan media video dengan SAVI pada materi Dinamika Penerapan Pancasila Dari Masa Ke Masa. a) tahap pengumpulan informasi, yakni : Studi literatur, studi pustaka dan kisi-kisi instrument pengumpulan data b) tahap perencanaan, yakni : membuat scrip, registrasi powton,editing animasi,voice over, filmora, penggabungan video animasi dan export. c) tahap pengembangan, yakni : story board dan layout. d) tahap validasi. Yakni : Ahli materi dan Ahli media. 2) Hasil Uji
\end{abstract}

\section{Paris Langkis}

Vol.1 Nomor 2, Maret 2021 
Kelayakan Media Video Dengan SAVI Pada Materi Dinamika Penerapan Pancasila Dari Masa Ke Masa. a) validasi ahli materi dan ahli media, dapat diketahui hasil validasi ahli materi sebesar 3,75 dan jika dikonversikan ke dalam bentuk persentase adalah sebesar 75\%, b) hasil validasi ahli media sebesar 3,87, dan jika dikonversikan ke dalam bentuk persentase adalah sebesar 88\%.Pendekatan SAVI berpangkal pada empat komponen yaitu Somatic, Audiotory, Visual, Intelegency.Somatic mengutamakan aspek jasmaniah, audiotory pada segi pemanfaatan suara (audio), visual pada penggunaan media video atau lainnya yang dapat dilihat, sedangkan intelegency penekanan pada kegiatan berpikir untuk memecahkan masalah.

Kata Kunci : Pembelajaran SAVI, Media Video

\begin{abstract}
:
This study aims to produce instructional media products in the form of videos on PPkn subjects on the dynamics of applying Pancasila from time to time. The application of learning using the SAVI approach is that this approach can be applied to existing classroom learning and is an alternative in increasing students' understanding and creativity in learning. In addition, the SAVI approach can direct and guide students to learn actively both physically and intellectually and optimize the use of the students' senses. So that they more easily absorb the information presented. This research is a type of research and development or Research and Development (RED) through the following stages: 1) the information collection stage, namely: literature study, literature study and data collection instrument grid. 2) the planning stage, namely: making scrip, powton registration, animation editing, voice over, filmora, merging animated videos and exporting. 3) development stage, namely: story board and layout. 4) the validation stage. Namely: material expert and media expert. Feasibility test on PPKn experts and media experts with the subject of due diligence (teachers). The feasibility test is carried out with a validation sheet. The research instrument was a validation sheet, suggestions and comments as well as a questionnaire. The results of this study are. 1) Steps to develop video media with SAVI on the dynamics of the application of Pancasila from time to time. a) the information collection stage, namely: literature study, literature study and data collection instrument grid b) the planning stage, namely: creating scripts, powton registration, animation editing, voice over, filmora, merging animated videos and exporting. c) the development stage, namely: story board and layout. d) the validation stage. Namely: material expert and media expert. 2) Feasibility Test Results for Video Media with SAVI on the Dynamics of Application of Pancasila from Time to Time. a) validation of material experts and media experts, it can be seen that the results of validation by material experts are 3.75 and if converted into a percentage is $75 \%, b$ ) the validation results of media experts are 3.87, and if converted into a percentage is by $88 \%$. The SAVI approach is based on four components, namely Somatic, Audiotory, Visual, Intelligence. Somatic prioritizes physical aspects, audiotory in terms of sound utilization (audio), visuals on the use of video or other visible media, while intelligence emphasizes thinking activities to solve problems.
\end{abstract}

Keywords: SAVI Learning, Video Media

\title{
Paris Langkis
}

Vol.1 Nomor 2, Maret 2021 


\section{A. PENDAHULUAN}

Di era globalisasi seperti saat ini dituntut untuk serba cepat, teknologi serba canggih dan arus informasi pun berjalan sangat cepat.Berbagai kemudahan bisa diperoleh masyarakat secara cepat melalui fasilitas teknologi. Kompetisi akan semakin ketat dan berat untuk bisa tetap bertahan dan sukses menghadapi tantangan dunia global ini. Oleh karena itu generasi muda harus dibekali kemampuan untuk bisa kreatif, kompetitif, kooperatif, dan dunia pendidikan memegang peranan penting untuk membekali generasi muda dengan ketiga hal tersebut.

Didalam dunia pendidikan guru sebagai salah satu komponen pendidikan dan merupakan suatu bidang profesi, mempunyai peranan yang sangat penting didalam proses belajar mengajar untuk membawa anak didiknya kepada kedewasaan dalam arti yang sangat luas. Bahkan boleh dikatakan bahwa keberhasilan suatu proses belajar mengajar ini sebagian besar terletak di tangan guru. Sementara penerapan pembelajaran yang monoton akan mengakibatkan kebosanan pada peserta didik, dikarenakan pembelajaran hanya menggunakan sistem atau cara yang sama tiap melakukan proses pembelajaran. Sebaliknya, jika pendidik menggunakan berbagai macam pendekatan pembelajaran maka peserta didik akan lebih termotivasi dan aktif dalam belajar, sehingga akan mempengaruhi terhadap hasil belajar peserta didik. Berdasarkan hal tersebut pendidik dituntut harus mampu menciptakan suasana kelas yang kondusif dan menghindari halhal yang monoton dan membosankan. Salah satunya dengan menggunakan pendekatan dalam pembelajaran yang mampu menstimulasi peserta didik agar berperan aktif dalam proses pembelajaran, yaitu dengan menerapkan pendekatan Somatic, Auditory, Visual, Intelegency (SAVI).

Alasan penerapan pembelajaran dengan menggunakan pendekatam SAVI adalah pendekatan ini dapat diterapkan dalam pembelajaran yang ada dikelas dan merupakan suatu alternatif dalam meningkatkan pemahaman dan kreativitas siswa dalam pembelajaran.Selain itu pendekatan SAVI dapat mengarahkan dan membimbing peserta didik untuk belajar secara aktif baik secara fisik maupun intelektual dan mengoptimalkan penggunaan indera yang dimiliki peserta didik. Sehingga peserta didik mudah menyerap informasi yang disampaikan. Ketika peserta didik belajar dengan aktif, berarti yang mendominasi aktifitas pembelajaran, sehingga bukan hanya guru yang aktif dalam pembelajaran.

Dari uraian tersebut jelas bahwa proses pembelajaran pada mata pelajaran PPKn sebaiknya dapat menerapkan pendekatan pembelajaran melalui model pembelajaran seperti halnya penggunaan pendekatan Somatic, Auditory, Visual, Intelegency (SAVI) untuk menunjang dan membantu mempermudah peserta didik dalam memahami serta penguasaan materi.

Bagi penulis faktor-faktor ini merupakan cerminan serta gambaran dari kegiatan belajar peserta didik, persoalannya sekarang adalah disatu sisi peserta didik harus melaksanakan kegiatan belajar, karena belajar merupakan kewajiban dari peserta didik itu sendiri.Sebab itu perlu dilakukan penelitian seputar kegiatan belajar peserta didik. Atas dasar asumsi dan argumen - argumen yang diatas itulah penulis ingin mengkaji lebih jauh tentang: "Pendekatan Pembelajaran Somatic Auditory Visual Intelegency (Savi) Dengan Menggunakan Media Video Pada Materi Dinamika Penerapan Pancasila dari Masa ke Masa Di Kelas IX”.

\section{Paris Langkis}

Vol.1 Nomor 2, Maret 2021 


\section{B. KAJIAN PUSTAKA}

Pendekatan belajar SAVI (Somatic, Audiotory, Visual, Intelegency) merupakan pendekatan yang melibatkan siswa sehingga siswa dituntut untuk melakukan sesuatu dengan melibatkan semua panca indra (melakukan sesuatu, mendengarkan, melihat, dan befikir). Dave meier merupakan pendidik, trainer, sekaligus penggagasan model accelerated learning. Salah satu strategi pembelajarannya adalah apa yang dikenal dengan SAVI. Berikut ini adalah cara-cara yang bisa menjadi starting point guru dalam melaksanakan pembelajaran SAVI.

$S$ : Somatic-learning by doing

A: Audotory-learning by hearing

V: Visuallearning by seeing

I: Intellectuallearning by thinking

a. Somatic

Somatic adalah belajar dengan bergerak dan berbuat."Somatic" berasal dari bahasa yunani yaitu tubuh-soma.Jika dikaitkan dengan belajar maka dapat diartikan belajar dengan bergerak dan berbuat. Belajar somatic berarti belajar dengan indra peraba, kinestetis, praktis- melibatkan fisik dan menggunakan serta menggerakkan tubuh sewaktu belajar. Karena itu, dapat dikatakan bahwa belajar somatic lebih mementingkan jasmani.Peserta didik tidak hanya diam di kursi belajar pada saat pembelajaran di kelas, tetapi juga memperagakan konsep sambil memberikan kesempatan pada siswa untuk mempelajari langkah demi langkah.Penelitian neurologi menemukan bahwa "pikiran tersebar di seluruh tubuh (Meier, 2002:93). Peserta didik akan lebih aktif secara fisik dengan merangsang pikiran dan tubuh. Tidak semua pembelajaran memerlukan aktivitas fisik, tetapi memang diperlukan adanya kombinasi antara kedua hal yaitu secara aktif dan pasif.

\section{b. Auditori}

Auditory adalah belajar dengan berbicara dan mendengar. Pikiran auditory kita lebih kuat daripada apa yang kita sadari, telinga kita terus menerus menangkap dan menyimpan informasi bahkan tanpa kita sadari. Ketika kita membuat suara sendiri dengan berbicara beberapa area penting diotak kita menjadi aktif.

c. Visual

Visual adalah belajar dengan mengamati dan menggambarkan.Dalam otak kita terdapat lebih banyak perangkat untuk memproses informasi visual daripada semua indera yang lain. Setiap siswa yang menggunakan visual-nya lebih mudah belajar jika dapat melihat apa yang sedang dibicarakan seorang penceramah atau sebuah buku atau program computer. Secara khususnya pembelajar visual yang baik jika mereka dapat melihat contoh dari dunia nyata, diagram, peta gagasan, ikon dan sebagainya ketika belajar.

d. Intelegency (intelektual)

Intelektual adalah belajar dengan memecahkan masalah dan merenung.Tindakan pembelajar yang melakukan sesuatu dengan pikiran mereka secara internal ketika menggunakan kecerdasan untuk merenungkan suatu pengalaman dan menciptakan hubungan, makna, rencana, dan nilai

\section{Paris Langkis}

Vol.1 Nomor 2, Maret 2021 
dari pengalaman tersebut.Hal ini diperkuat dengan makna intelektual adalah bagian diri yang merenung, mencipta, dan memecahkan masalah.

Dari uraian diatas proses belajar dapat optimal jika keempat unsur SAVI ada di dalam suatu pembelajaran. Siswa yang dapat belajar sedikit dengan menyaksikan video pembelajaran (V), tetapi mereka dapat belajar jauh lebih banyak jika mereka dapat melakukan sesuatu saat proses pembelajaran berlangsung (S), membicarakan apa yang sedang mereka pelajari (A), dan memikirkan cara menerapkan informasi dalam video pembelajaran tersebut dalam kehidupan sehari-hari (I). mereka dapat memecahkan masalah (I), jika mereka secara simultan menggerakkan sesuatu (S) untuk menghasilkan gambaran atau produk tiga dimensi (V) dan membicarakan yang sedang mereka lakukan (A).

\section{Pembelajaran PPKn}

Pendidikan pancasila dan kewarganegaraan adalah mata pelajaran yang bertujuan untuk membentuk peserta didik menjadi manusia yang memiliki rasa kebangsaan dan cinta tanah air dalam konteks nilai dan moral Pancasila, kesadaran berkonstitusi UndangUndang Dasar Negara Republik Indonesia 1945, nilai dan semangat Bhinneka Tunggal Ika, serta komitmen Negara Kesatuan Republik Indonesia.Pancasila sebagai pandangan hidup sering di sebut juga way of life, pegangan hidup, pedoman hidup, pandangan dunia, atau petunjuk hidup. Pancasila merangkum nilai-nilai yang sama yang terkandung dalam adat istiadat, kebudayaan dan agama-agama yang ada di Indonesia. Dengan demikian, pancasila sebagai pandang hidup mencerminkan jiwa dan kepribadian bangsa.Pendidikan pancasila dan kewarganegaraan adalah mata pelajaran yang berusaha membina perkembangan moral peserta didik sesuai dengan nilai-nilai pancasila, agar dapat mencapai perkembangan secara optimal dan dapat diwujudkan dalam kehidupan seharihari.

\section{Media video}

\section{Pengertian Media video}

Video merupakan teknologi pengiriman sinyal elektronik dari suatu gambar yang bergerak. Aplikasi umum dari sinyal video yaitu seperti televisi, namun juga ia bisa juga digunakan dalam aplikasi lain di dalam bidang teknik, saintifik, produksi dan juga keamanan. Berdasarkan bahasa, kata video ini berasal dari kata Latin, "Saya lihat"

Media video yang digunakan dalam proses belajar mengajar memiliki banyak manfaat dan keuntungan, diantaranya adalah video merupakan pengganti alam sekitar dan dapat menunjukkan objek yang secara normal tidak dapat dilihat siswa seperti materi proses pencernaan makanan dan pernafasan, video dapat menggambarkan suatu proses secara tepat dan dapat dilihat secara berulang-ulang, video juga mendorong dan meningkatkan motivasi siswa untuk tetap melihatnya. (Azhar Arsyad, 2011: 49)

\section{METODOLOGI PENELITIAN}

Borg \& Gall dalam Nana Syaodih Sukmadinata (2006: 169-170) memaparkan empat langkah

\section{Paris Langkis}

Vol.1 Nomor 2, Maret 2021 
pelaksanaan strategi penelitian dan pengembangan sebagai berikut:

1. Penelitian dan pengumpulan data (research and information collecting) yang meliputi pengukuran kebutuhan, studi literatur, penelitian dalam skala kecil, dan pertimbanganpertimbangan dari segi nilai.

2. Perencanaan (planning) yaitu menyusun rencana penelitian, meliputi kemampuankemampuan yang diperlukan dalam pelaksanaan penelitian, rumusan tujuan yang hendak dicapai dengan penelitian tersebut, desain atau langkah-langkah penelitian, dan kemungkinan dalam lingkup terbatas.

3. Pengembangan draf produk (develop preliminary form of product). Pengembangan video, proses pengembangan video, dan instrumen evaluasi.

4. Uji kelayakan (feasibility test). Uji kelayakan pada ahli PPKn dan ahli media dengan subjek uji kelayakan (guru).Uji kelayakan dilakukan dengan lembar validasi.

Prosedur penelitian yang dilakukan peneliti dalam pengembangan ini diadaptasi dari langkah langkah pengembangan yang dikembangkan oleh Borg \& Gall tersebut dengan pembatasan.Borg \& Gall (dalam Emzir, 2013: 271) menyatakan bahwa dimungkinkan untuk membatasi penelitian dalam skala kecil, termasuk membatasi langkah penelitian.Penerapan langkah-langkah pegembangannya disesuaikan dengan kebutuhan peneliti. Mengingat keterbatasan waktu dan dana yang dimiliki oleh peneliti, maka langkah-langkah tersebut disederhanakan menjadi empat langkah pengembangan. Langkah pengembangan yang dilakukan oleh peneliti adalah:

1. Tahap pengumpulan data

Tahap pengumpulan data dilakukan untuk mengetahui kebutuhan dalam mengembangkan media video. Tahap pengumpulan data dilakukan dengan cara studi literatur dan studi pustaka.

a. Studi literatur dilakukan untuk mengetahui kebutuhan metode pengembangan media video. Studi literatur dilakukan dengan cara analisis kurikulum yang berlaku di sekolah.

b. Studi pustaka mengenai teori yang berhubungan dengan sumber belajar bentuk media video untuk pembelajaran PPKn di SMP serta studi pustaka mengenai materi dinamika penerapan pancasila dari masa ke masa.

2. Tahap perencanaan yaitu menyusun rencana penelitian, meliputi kemampuan-kemampuan yang diperlukan dalam pelaksanaan penelitian, rumusan tujuan yang hendak dicapai dengan penelitian tersebut, desain atau langkah-langkah penelitian, dan kemungkinan dalam lingkup terbatas.

3. Tahap pengembangan produk

Tahap pengembangan produk dimulai dengan pengumpulan bahan, pengelolaan bahan, dan terakhir adalah produksi. Bahan-bahan yang dikumpulkan berupa media video sebagai sajian utama dan bahan lain untuk melengkapi rubrik yang telah direncanakan.

4. Tahap validasi

Video pembelajaran yang telah diproduksi, kemudian dievaluasi.Bentuk dari evaluasi media video adalah validasi.Validasi dilakukan dalam dua tahap.Tahap I adalah validasi

\section{Paris Langkis}

Vol.1 Nomor 2, Maret 2021 
oleh ahli materi dan ahli media.Melalui tahap ini diperoleh data kelayakan produk dan saran dari ahli.

\section{HASIL PEMBAHASAN}

1. Langkah - langkah pengembangan media video dengan SAVI pada materi Dinamika Penerapan Pancasila Dari Masa Ke Masa

Penelitian yang dilakukan peneliti dalam pengembangan ini diadaptasi dari langkahlangkah pengembangan yang dikembangkan oleh Borg \& Gall tersebut dengan pembatasan. Borg \& Gall (dalam Emzir, 2013:271) Penerapan langkah-langkah pegembangannya disesuaikan dengan kebutuhan peneliti yaitu :

a. Tahap pengumpulan informasi

Tahap ini diawali dengan melakukan tinjauan standar isi. Tinjauan standar isi dilakukan dengan cara membuat pemetaan Standar Kompetensi (SK) dan Kompetensi Inti (KI), hasil pemetaan SK dan KI dapat dilihat pada lampiran. Berdasarkan tahapan tersebut diperoleh materi yang akan dikembangkan dalam video pembelajaran menggunakan pendekatan Somatic, Audiotory, Visual, Intellegency (SAVI) yaitu dinamika penerapan pancasila dari masa ke masa. Setelah materi yang dikembangkan sudah ditentukan maka langkah selanjutnya adalah melakukan studi pustaka untuk mengumpulkan materi dinamika penerapan pancasila dari masa ke masa.

b. Tahap perencanaan

Tahap kedua ini terdiri dari pembuatan media video animasi yang terdiri dari :

1) Membuat scrip/narasi (skenario)

Skenario ini berfungsi sebagai pemandu ke mana arah pembicaraan narrator ketika direkam nanti. Tulis ringkasan materi bahan ajar yang nantinya bisa dibacakan pada saat proses record pada animasi video pembelajaran

2) Registrasi Powton

Registrasi aplikasi powton untuk memulai membuat animasi freediting dengan ketentuan jangka waktu selama 72 jam (3 hari)

3) Editing animasi pada powton

Ketika sudah menyusun seluruh materi, langkah selanjutnya ialah membuat animasi beserta penjelasan materi dengan aplikasi powton yang sudah di registrasi

4) Voice over

Voice over adalah proses pemberian suara pada konten digital (mulai dari gambar hingga video) untuk menyampaikan pesan, baik dalam bentuk narasi maupun dialog.

5) Filmora

Filmora adalah aplikasi video editor pada software, aplikasi ini bersifat ringan dan sangat mudah dipelajari.Filmora hadir dalam dua versi, yaitu versi biasa dan versi Pro.

6) Penggabungan video animasi

\section{Paris Langkis}

Vol.1 Nomor 2, Maret 2021 
Ketika editing animasi pada powton dan ilustrasi sudah terkumpul, saatnya mengedit video pembelajaran, ada banyak software yang bisa digunakan, misalnya saja Movie Maker dari Windows, Adobe Premiere, Corel Video Studio, dan filmoralika video dan ilustrasi sudah tergabung, hasil akhir dari video adalah compact disk (CD) atau lainnya yang sesuai dengan ketentuan.

7) Export hasil editing dari filmora (tahap akhir)

Setelah proyek pembuatan video selesai, semua editan telah selesai dan tinggal di simpan dan dibagikan kepada banyak orang, dalam aplikasi ini banyak opsi yang ditawarkan. Anda dapat menyimpan video dengan berbagai format video yang Anda inginkan, seperti AVI, WMV, MOV, FLV, MP4, MKV, dll. kita juga bisa menyimpan untuk perangkat mobile.

c. Tahap pengembangan

Pada tahap ini dilakukan pembuatan produk media video dengan pendekatan pembelajaran Somatic Auditory Visual Intelegency (SAVI). Langkah-langkah yang dilakukan yaitu;

1) Membuat story board. Story board dibuat dengan tujuan mempermudah dalam pembuatan media dan untuk menentukan tahap pengembangan selanjutnya, agar bagian-bagian dari media video dapat tersusun dengan baik. Story board dibuat dengan cara menggambar sketsa di atas kertas, sketsa yang telah selesai dibuat lalu digambar ulang menggunakan komputer.

Story board lalu dijadikan acuan membuat layout. Layout dibuat dengan memperhatikan aspek warna dan komposisi dalam pengembangan media video dengan SAVI

2) Layout yang telah selesai dibuat lalu diisi dengan materi dinamika penerapan pancasila dari masa ke masa. Materi di dalam media video menggunakan pendekatan Somatic, Audiotory, Visual, Intellegency (SAVI) ini terdiri dari empat sub materi yaitu, masa awal kemerdekaan, masa orde lama, masa orde baru dan masa reformasi. Layout yang digunakan dalam media video ini akan dibuat dengan axial layout dimana memiliki tampilan visual yang kuat di tengah halaman dengan tampilan element pendukung di sekeliling gambar utama biasanya berupa gambar atau tulisan yang berhubungan dengan tampilan di tengah halaman sebagai titik pusatnya.

Menurut Adikara (wawancara tgl 22 Mei 2018) mengatakan bahwa layout adalah suatu sistem keterhubungan antar unsur pembentuknya untuk membangun sutau kesatuan.Layout dalam desain komunikasi visual sebagai suatu ketertiban untuk menempatkan teks dan gambar.

d. Tahap validasi

Tahap validasi media dilakukan agar media pembelajaran interaktif yang dikembangkan dapat diketahui kelayakannya berdasarkan penilaian ahli materi dan ahli media. Validasi media pembelajaran interaktif dilakukan oleh:

a. Ahli materi yang berkompeten di bidang Pendidikan kewaranegaraan

\section{Paris Langkis}

Vol.1 Nomor 2, Maret 2021 
b. Ahli media yang berkompeten dalam bidang media video menggunakan pendekatan Somatic, Audiotory, Visual, Intellegency (SAVI).

Data penilaian hasil validasi ahli materi tersaji dalam tabel lampiran 5, sedangkan data penilaian hasil validasi ahli media tersaji dalam tabel lampiran 6. Produk media yang sudah divalidasi selanjutnya direvisi sesuai dengan saran dan masukan ahli saat proses validasi Setelah media video selesai direvisi kemudian dilakukan tahap ujicoba penggunaan media dalam pembelajaran di kelas, yang bertujuan untuk mengetahui respon guru terhadap media video dengan pendekatan pembelajaran Somatic Auditory Visual Intelegency (SAVI) yang dikembangkan.Tahap ujicoba dilaksanakan di SMP PANCASILA, Palangka Raya. Ujicoba dilakukan dengan cara penggunaan media dalam pembelajaran di kelas oleh guru. Setelah menggunakan media, guru di wawancara untuk diminta tanggapan, saran, dan komentarnya mengenai media pembelajaran interaktif yang dikembangkan.

Media video dengan pendekatan pembelajaran Somatic Auditory Visual Intelegency (SAVI)yang telah melalui ujicoba lalu direvisi kembali berdasarkan saran dan masukan dari guru.Hasil akhir penelitian dan pengembangan ini adalah produk media video untuk pembelajaran PPKN SMP kelas IX.Produk media video dengan pendekatan pembelajaran Somatic Auditory Visual Intelegency (SAVI) inidikemas dalam CD. Validitas adalah ketepatan dan kecermatan instrumen dalam menjalankan fungsi ukurnya. Artinya, validitas menunjukkan bahwa instrumen tersebut mampu mengungkap dengan akurat dan teliti data mengenai atribut yang ia rancang untuk mengukurnya. Validitas berkaitan dengan tujuan ukur, maka setiap skala hanya dapat menghasilkan data yang valid untuk satu tujuan ukur yang spesifik pula (Azwar, 2016:10). Menurut Sugiyono (2015:172-) hasil penelitian dikatakan valid apabila terdapat kesamaan antara data yang terkumpul dengan data yang sesungguhnya. Instrumen yang valid berarti alat ukur yang digunakan untuk mendapatkan data itu valid. Valid artinya instrumen tersebut dapat digunakan untuk mengukur apa yang seharusnya diukur. Instrumen yang valid merupakan syarat mutlak untuk mendapatkan hasil penelitian yang valid.Validitas instrumen yang digunakan adalah validitas konstruk dan validitas isi.

Setelah media video selesai kemudian dilakukan tahap ujicoba penggunaan media dalam pembelajaran di kelas, yang bertujuan untuk mengetahui respon guru terhadap media video dengan pendekatan pembelajaran Somatic Auditory Visual Intelegency (SAVI) yang dikembangkan.Tahap ujicoba dilaksanakan di SMP PANCASILA, Palangka Raya. Ujicoba dilakukan dengan cara penggunaan media dalam pembelajaran di kelas oleh guru. Setelah menggunakan media, guru di wawancara untuk diminta tanggapan, saran, dan komentarnya mengenai media pembelajaran interaktif yang dikembangkan. Media video dengan pendekatan pembelajaran Somatic Auditory Visual Intelegency (SAVI)yang telah melalui ujicoba berdasarkan saran dan masukan dari guru. Hasil akhir penelitian dan pengembangan ini adalah produk media video untuk pembelajaran PPKN SMP kelas IX.Produk media video dengan pendekatan pembelajaran Somatic Auditory Visual Intelegency (SAVI) inidikemas dalam CD.

\section{Paris Langkis}

Vol.1 Nomor 2, Maret 2021 
2. Hasil Uji Kelayakan Media Video Dengan SAVI Pada Materi Dinamika Penerapan Pancasila Dari Masa Ke Masa

Pada tahap uji kelayakan media yang telah dikembangkan penguji melakukan uji kelayakan dengan melakukan uji validasi ke ahli materi, ahli media dan wawancara guru PPKn.Data yang diperoleh melalui instrumen penilaian pada saat uji coba dianalisis dengan menggunakan statistik deskriptif kualitatif. Analisis ini dimaksud untuk menggambarkan karakteristik data pada masingmasing variabel. Dengan cara ini diharapkan dapat mempermudah memahami data untuk proses selanjutnya. Hasil analisis data digunakan sebagai dasar untuk merevisi produk media yang dikembangkan.

Menurut Suherman mengemukakan pendekatan dalam pembelajaran adalah suatu jalan, cara atau kebijaksanaan yang ditempuh oleh guru atau siswa dalam pencapaian tujuan pembelajaran dilihat dari sudut bagaimana proses pembelajaran atau materi pembelajaran itu, umum atau khusus.

\section{E. SARAN}

Berdasarkan hasil penelitian pembahasan dan kesimpulan diatas, maka saran yang dapat diberikan pada penelitian ini adalah : Sesuai dengan hasil penelitian, bahwa media video pembelajaran pada materi dinamika penerapan pancasila dari masa ke masa berdasarkan validasi kelayakan oleh para ahli media di nyatakan sangat layak untuk digunakan, oleh karena itu dapat diterapkan dalam proses belajar mengajar disekolah dan cocok di aplikasikan dalam pembelajaran daring pada saat ini Diharapkan adanya penelitian lebih lanjut terhadap Pendekatan Pembelajaran Somatic Auditory Visual Intelegency (SAVI) dengan menggunakan media video pada materi dinamika penerapan pancasila dari masa ke masa di kelas IX, sehingga dapat memudahkan guru dalam meningkatkan prestasi belajar peserta didik.

\section{F. KESIMPULAN}

Berdasarkan hasil penelitian dan pengembangan ini dapat disimpulkan bahwa:Penelitian dan pengembangan ini menghasilkan produk berupa media video pembelajaran pada materi dinamika penerapan pancasila dari masa ke masa dengan menggunakan pendekatan pembelajaran Somatic Auditory Visual Intelegency (SAVI) di kelas IX SMP. Tahapan yang dilakukan untuk menghasilkan media video dengan pendekatan pembelajaran Somatic Auditory Visual Intelegency (SAVI) sebagai berikut: a) tahap pengumpulan informasi; b) tahap perencanaan; c) tahap pengembangan; dan d) tahap validasi . Berdasarkan validasi ahli materi dan ahli media, dapat diketahui hasil validasi ahli materi sebesar 3,75 dan jika dikonversikan ke dalam bentuk persentase adalah sebesar $75 \%$ dan hasil validasi ahli media sebesar 3,87, dan jika dikonversikan ke dalam bentuk persentase adalah sebesar $88 \%$. Dengan demikian penilaian ahli media tentang media video pada materi dinamika penerapan pancasila dari masa ke masa dengan menggunakan pendekatan pembelajaran Somatic Auditory Visual Intelegency (SAVI) di kelas IX tersebut sangat

\section{Paris Langkis}

Vol.1 Nomor 2, Maret 2021 
layak dijadikan sebagai media pembelajaran.Pendekatan SAVI berpangkal pada empat komponen

yaitu Somatic, Audiotory, Visual, Intelegency.Somatic mengutamakan aspek jasmaniah, audiotory pada segi pemanfaatan suara (audio), visual pada penggunaan media video atau lainnya yang dapat dilihat, sedangkan intelegency penekanan pada kegiatan berpikir untuk memecahkan masalah.

Dalam mengembangkan produk berupa media video pada materi dinamika penerapan pancasila dari masa ke masa dengan menggunakan pendekatan pembelajaran Somatic Auditory Visual Intelegency (SAVI) di kelas IX belum adanya pengambilan gambar secara penuh tetapi sebagian besar cuplikan gambar dan video hanya mengunduh dari youtube.Hal ini dikarenakan keterbatasan waktu dan referensi.Media video dengan menggunakan pendekatan pembelajaran Somatic Auditory Visual Intelegency (SAVI) merupakan produk baru yang belum pernah dikembangkan sebelumnya di program studi PPKN Universitas Palangka Raya, oleh karena itu perlu dikembangkan produk yang berkelanjutan. Pengembangan produk lebih lanjut tidak hanya dapat dilakukan pada materi dinamika penerapan pancasila dari masa ke masa saja tetapi dapat dilakukan pada materi atau pembelajaran ilmu lain.

\section{DAFTAR PUSTAKA}

Al Muchtar, S. (2015). Dasar Penelitian Kualitatif. Bandung: Gelar Pustaka Mandiri.

Arief S. Sadiman. (2009). Media Pendidikan. Jakarta: PT Raja Grafindo Persada

Aris, shoimin. 2014. 68 model pembelajaran inovatif dalam kurikulum 2013.Yogyakarta : Ar-Ruzz Media

Arikunto, Suharsimi. (2012). Prosedur Penelitian.Jakarta:n Rineka Cipta.

Arikunto, S. 2006. Prosedur Penelitian Suatu Pendekatan Praktik. Jakarta: Rineka Cipta.

Cecep Kustandi dan Bambang Sutjipto.(2013). Media Pembelajaran Manual dan Digital Edisi Kedua. Bogor: Ghalia Indonesia.

Dave Meier. The Accelerated Learning Handbooks: Panduan Kreatif dan Efektif Merancang Program Pendidikan dan Pelatihan. Diterjemahkan Oleh Rahmani Astuti (Bandung:Kaifa. 2005)

Daryanto.(2010). Media Pembelajaran Peranannya Sangat Penting Dalam Mencapai Tujaun Pembelajaran. Yogyakarta: Gava Media.

Majid, A. 2008.Perencanaan Pembelajaran. Bandung: PT. Remaja Rosdakarya.

Margono. 2010. Metode-metode Penelitian. Jakarta: Lista Fariska Putra

Miftahul Huda, Model-Model Pengajaran dan Pembelajaran (Jogyakarta: Pustaka pelajar, 2013)

Aji. (2013). Pendidikan Pancasila di Perguruan Tinggi Implementasi Nilai-Nilai Karakter Bangsa. Jakarta: Ghalia Indonesia.

Moh.Nazir. 2011. Metode Penelitian. Bogor: Penerbit Ghalia Indonesia

Rusman.(2012). Belajar dan Pembelajaran Berbasis Komputer Mengembangkan Profesionalisme Guru Abad 21. Bandung: Alfabeta.

Sugiyono. 2013. Metode Penelitian Pendidikan (Pendekatan Kuantitatif, Kualitatif, dan $R$ E D). Bandung: Alfabeta.

Sugiyono.2006. Metode Penelitian Kuantitatif, Kualitatif dan R E D. Bandung:Alfabeta

\section{Paris Langkis}

Vol.1 Nomor 2, Maret 2021 
Sugiyono. (2013). Metode Penelitian Kuantitatif, Kualitatif dan R\&D. Bandung: Alfabeta.CV Sudjana, Nana. (2016). Penilaian Hasil Proses Belajar Mengajar. Bandung: Rosdikarya

Permendikbud. (2014). Peraturan Menteri Pendidikan dan Kebudayaan Republik Indonesia Nomor 59

Tahun 2014 tentang Kurikulum 2013 sekolah menengah Atas/Madrasah Aliyah. Jakarta: Kementrian Pendidikan dan Kebudayaan.

Djam'an Satrio dan Aan Kurniawan, Metodologi Penelitian Kualitatif, Bandung: Alfabeta, 2014.

Sugiyono, Metode Penelitian Pendidikan Pendekatan Kuantitatif, Kualitatif, dan REDD, Bandung: Alfabeta, 2015. 